\title{
DISCONTINUOUS HYDRATION ON THE GERMINATION OF Mimosa caesalpiniifolia AND Pityrocarpa moniliformis SEEDS UNDER WATER STRESS ${ }^{1}$
}

\author{
JOSEFA PATRÍCIA BALDUINO NICOLAU ${ }^{2}$, FRANCISCO EUDES DA SILVA ${ }^{2}$, FRANCIVAL CARDOSO FELIX ${ }^{2 *}$, \\ SALVADOR BARROS TORRES ${ }^{3}$, MAURO VASCONCELOS PACHECO ${ }^{2}$, MÁRCIO DIAS PEREIRA ${ }^{2}$
}

\begin{abstract}
The use of discontinuous hydration cycles can act in improving seed germination and seedling initial growth under water stress. In this context, the objective of this study was to evaluate the effect of discontinuous hydration on the germination of Mimosa caesalpiniifolia and Pityrocarpa moniliformis seeds under water stress. For this, seeds of these species were subjected to 0 (without hydration), 2 and 4 hydration cycles $(18 \mathrm{~h})$ and dehydration (12 and $18 \mathrm{~h}$, respectively), with subsequent germination under water stress simulated for osmotic potentials of 0.0 (distilled water), $-0.2,-0.4,-0.6$ and $-0.8 \mathrm{MPa}$. Seedlings were evaluated using tests of germination, germination speed index, mean germination time and seedling length. Discontinuous hydration in M. caesalpiniifolia and P. moniliformis seeds hampers germination and vigor of seedlings under water stress up to $-0.6 \mathrm{MPa}$. However, the use of two cycles in P. moniliformis favors germination under more severe water stress $(-0.8 \mathrm{MPa})$.
\end{abstract}

Keywords: Fabaceae. Hydration cycles. Ecophysiology of germination. Forest seeds.

\section{HIDRATAÇÃO DESCONTÍNUA NA GERMINAÇÃO DE SEMENTES DE Mimosa caesalpiniifolia E Pityrocarpa moniliformis SOB ESTRESSE HÍDRICO}

RESUMO - A utilização de ciclos de hidratação descontínua pode atuar na melhoria da germinação de sementes e crescimento inicial de plântulas sob estresse hídrico. Nesse sentido, objetivou-se avaliar o efeito da hidratação descontínua na germinação de sementes de Mimosa caesalpiniifolia e Pityrocarpa moniliformis sob estresse hídrico. Para isso, sementes dessas espécies foram submetidas a 0 (sem hidratação), 2 e 4 ciclos de hidratação (18 h) e desidratação (12 e $18 \mathrm{~h}$, respectivamente), com posterior germinação sob estresse hídrico simulado para os potenciais osmóticos 0,0 (água destilada); -0,2; -0,4; - 0,6 e - $-0,8 \mathrm{MPa}$. As plântulas foram avaliadas por meio dos testes de germinação, índice de velocidade de germinação, tempo médio de germinação e comprimento de plântulas. A hidratação descontínua em sementes de $M$. caesalpiniifolia e $P$. moniliformis prejudica a germinação e o vigor de plântulas sob estresse hídrico até $-0,6 \mathrm{MPa}$. No entanto, a utilização de dois ciclos em P. moniliformis favorece a germinação sob estresse hídrico mais severo (-0,8 MPa).

Palavras-chave: Fabaceae. Ciclos de hidratação. Ecofisiologia da germinação. Sementes florestais.

\footnotetext{
${ }^{*}$ Corresponding author

${ }^{1}$ Received for publication in $01 / 06 / 2020$; accepted in $02 / 13 / 2020$.

${ }^{2}$ Specialized Academic Unit in Agricultural Sciences, Universidade Federal do Rio Grande do Norte, Macaíba, RN, Brazil; patricia.balduino@hotmail.com - ORCID: 0000-0003-2503-2378, f.eudes@academico.ifrn.edu.br - ORCID: 0000-0003-1206-1620, franciva1007@gmail.com - ORCID: 0000-0002-6518-5697, pachecomv@hotmail.com - ORCID: 0000-0002-0447-9800, marcioagron@yahoo.com.br - ORCID: 0000-0001-9729-6503.

${ }^{3}$ Department of Agronomic and Forestry Sciences, Universidade Federal Rural do Semiárido, Mossoró, RN, Brazil; sbtorres@ufersa.edu.br - ORCID: 0000-0003-0668-3327.
} 


\section{INTRODUCTION}

Mimosa caesalpiniaefolia Benth. and Pityrocarpa moniliformis (Benth.) Luckow \& R. W. Jobson (Fabaceae) are small, fast-growing tree species that occur in States of Northeast Brazil and in part of Minas Gerais, popularly known as 'sabiá' and 'catanduva', respectively. The former is used for reforestation, recovery of degraded areas and manufacture of posts (SOUSA et al., 2018), while the latter is used for beekeeping and forage purposes (AZERÊDO et al., 2016).

In dry forests, such as in Caatinga ecosystem, low rainfall, high temperatures and irregular rains throughout the year are common (AZERÊDO et al., 2016). In this environment, seed germination is usually hampered, because its occurrence requires favorable conditions of water and temperature (BASKIN; BASKIN, 2014). The momentary availability of water, caused by rapid and irregular rains, associated with high evaporation from the surface soil layers, directly affects seed germination in hydration and dehydration cycles, which prevents germination from being completed (LIMA; MEIADO, 2017).

Seed germination is directly linked to the movement of water through embryonic tissues (BEWLEY et al., 2013). Therefore, the loss of water due to drought or presence of high concentrations of solutes can interfere with the intracellular solution $\mathrm{pH}$, acceleration of degenerative reactions, denaturation of proteins and loss of membrane integrity, thus increasing the occurrence of damaged and abnormal seedlings (MARCOS-FILHO, 2015). In general, seeds under interruption of water supply due to soil drying can resume the process in the presence of new rains, without further damage to the internal tissues (LIMA et al., 2018).

The occurrence of hydration and dehydration cycles can enhance of rate of survival of native seeds of arid and semiarid regions during short and long drought periods, safeguarding the physiological characteristics resulting from previous hydration. These mechanisms presented in water memory contribute to the capacity of seeds to store physiological and biochemical changes caused by discontinuous hydration, besides providing uniformity, higher speed in germination and formation of vigorous seedlings (LIMA; MEIADO, 2017).

Discontinuous hydration prior to sowing has proven to be an efficient technique, as it positively increases germination, besides favoring the initial development of seedlings, as cited for Cereus jamacaru, Dodonaea viscosa, Ferocactus peninsulae, Helianthus annuus, Mammillaria mazatlanensis, Phaseolus vulgaris, Stenocereus alamosensis, S. gummosus, S. thurberi var. thurberi and Zea mays (LIMA et al., 2018). In this context, the objective of this study was to evaluate the effect of discontinuous hydration during the germination process in $M$. caesalpiniifolia and $P$. moniliformis seeds under water stress.

\section{MATERIAL AND METHODS}

M. caesalpiniifolia and $P$. moniliformis fruits came from populations (10 trees each), respectively, of the Experimental Area of the Escola Agrícola de Jundiaí (Macaíba/RN) (5 $5^{\circ} 53^{\prime} 35.12^{\prime \prime} \mathrm{S}$ and $35^{\circ} 21^{\prime}$ 47.03" W) and the Experimental Farm of the Universidade Federal Rural do Semiárido (Mossoró/ $\mathrm{RN})\left(5^{\circ} 03^{\prime} \mathrm{S}\right.$ and $\left.37^{\circ} 24^{\prime} \mathrm{W}\right)$, Rio Grande do Norte State, Brazil. These fruits were dried in the shade and manually processed, by eliminating seeds that were visibly damaged by insects and poorly formed.

At the beginning of the experimental phase, seed water content was determined by the drying oven method at $105 \pm 3{ }^{\circ} \mathrm{C}$ for $24 \mathrm{~h}$ (BRAZIL, 2009). For this, two subsamples of 50 seeds were used, and the results were expressed as a percentage (wet basis).

The hydration curves of the seeds of both species were constructed using four replicates of 50 seeds. Their tips were removed with cutting pliers in the region opposite to the micropyle in order to overcome physical dormancy and then the seeds were placed to hydrate on paper towels (Germitest ${ }^{\circledR}$ ) moistened with distilled water at volume equivalent to 2.5 times the dry paper weight. The papers were organized in the form of rolls and placed in a Biochemical Oxygen Demand (BOD) type germinator, at $25{ }^{\circ} \mathrm{C}$, with photoperiod of $12 \mathrm{~h}$ (BRAZIL, 2013). After that, the weight of the seeds was measured every $60 \mathrm{~min}$ on precision analytical scale $(0.001 \mathrm{~g})$ until the first seed germinated, which represented the end of the second phase of hydration. Therefore, the hydration curve was obtained through the alteration in seed biomass based on the initial water content $(\%)$, determining the time corresponding to $1 / 4$ of the period of Phase II (LIMA et al., 2018).

The dehydration curve was obtained based on the moisture loss of hydrated seeds, which were placed to dry on plastic trays lined with double layer of paper towel, kept in a laboratory environment $(25$ $\pm 3{ }^{\circ} \mathrm{C}$; $\mathrm{RH}=55 \%$ ) and weighed every $60 \mathrm{~min}$ until they reached the initial weight before hydration.

After obtaining hydration and dehydration curves (HD), the seeds were subjected to 0,2 and 4 cycles of discontinuous hydration $(1 / 4$ of the period of Phase II) for M. caesalpiniifolia (each cycle with 18 $\mathrm{h}$ hydration and $12 \mathrm{~h}$ dehydration) and $P$. moniliformis (each cycle with 18 h hydration and 18 $\mathrm{h}$ dehydration).

At the end of each cycle, the seeds were put to germinate under water stress simulated with polyethylene glycol solution (PEG 6000) at the osmotic potentials of 0.0 (distilled water); $-0.2,-0.4$, 
-0.6 and $-0.8 \mathrm{MPa}$ (VILLELA et al., 1991) and evaluated by the following tests: a) germination conducted as mentioned for the hydration curve, evaluating the percentage of normal seedlings formed until the fourteenth day for $M$. caesalpiniifolia and $P$. moniliformis, according to criteria established by Brazil (2009); b) germination speed index (GSI) and mean germination time (MGT) - determined by daily counting the number of seeds germinated after sowing of the germination test and calculated according to formulas proposed by Maguire (1962) and Labouriau (1983), respectively; c) seedling length - measurement of the root system and shoot of normal seedlings from the germination test. A ruler graduated in millimeters was used for this, and the results were expressed in centimeters per seedling ( $\mathrm{cm}$.seedling ${ }^{-1}$ ), dividing the sum of the length obtained in each replicate by the number of seedlings in each replicate.

The experimental design was completely randomized in a 3 x 5 factorial scheme (discontinuous hydration cycles $\mathrm{x}$ water potentials) with four replicates. The data were subjected to analysis of variance of the regression with $5 \%$ probability level, adopting the equations with the highest coefficients of determination. The statistical program used was BioEstat $^{\circledR}$, version 5.3 (AYRES et al., 2007).

\section{RESULTS AND DISCUSSION}

The seeds of $M$. caesalpiniifolia and $P$. moniliformis initially showed water contents of 8.7 and $9.8 \%$, respectively.

The hydration of $M$. caesalpiniifolia and $P$. moniliformis seeds lasted 36 and $38 \mathrm{~h}$, respectively (Figures 1A and 1B). Phase I lasted $12 \mathrm{~h}$ for both species, while Phase II lasted $24 \mathrm{~h}$ for $M$. caesalpiniifolia and $26 \mathrm{~h}$ for $P$. moniliformis. Thus, with 36 and $38 \mathrm{~h}$ of hydration, the seeds of $M$. caesalpiniifolia and $P$. moniliformis, respectively, reached Phase III, characterized by the emission of the primary root (Figures $1 \mathrm{~A}$ and $1 \mathrm{~B}$ ). Therefore, 18 $\mathrm{h}$ of hydration was the period determined as $1 / 4$ of Phase II to perform seed hydration cycles, with 12 and $18 \mathrm{~h}$ of dehydration for M. caesalpiniifolia and P. moniliformis, respectively (Figures $1 \mathrm{C}$ and 1D).
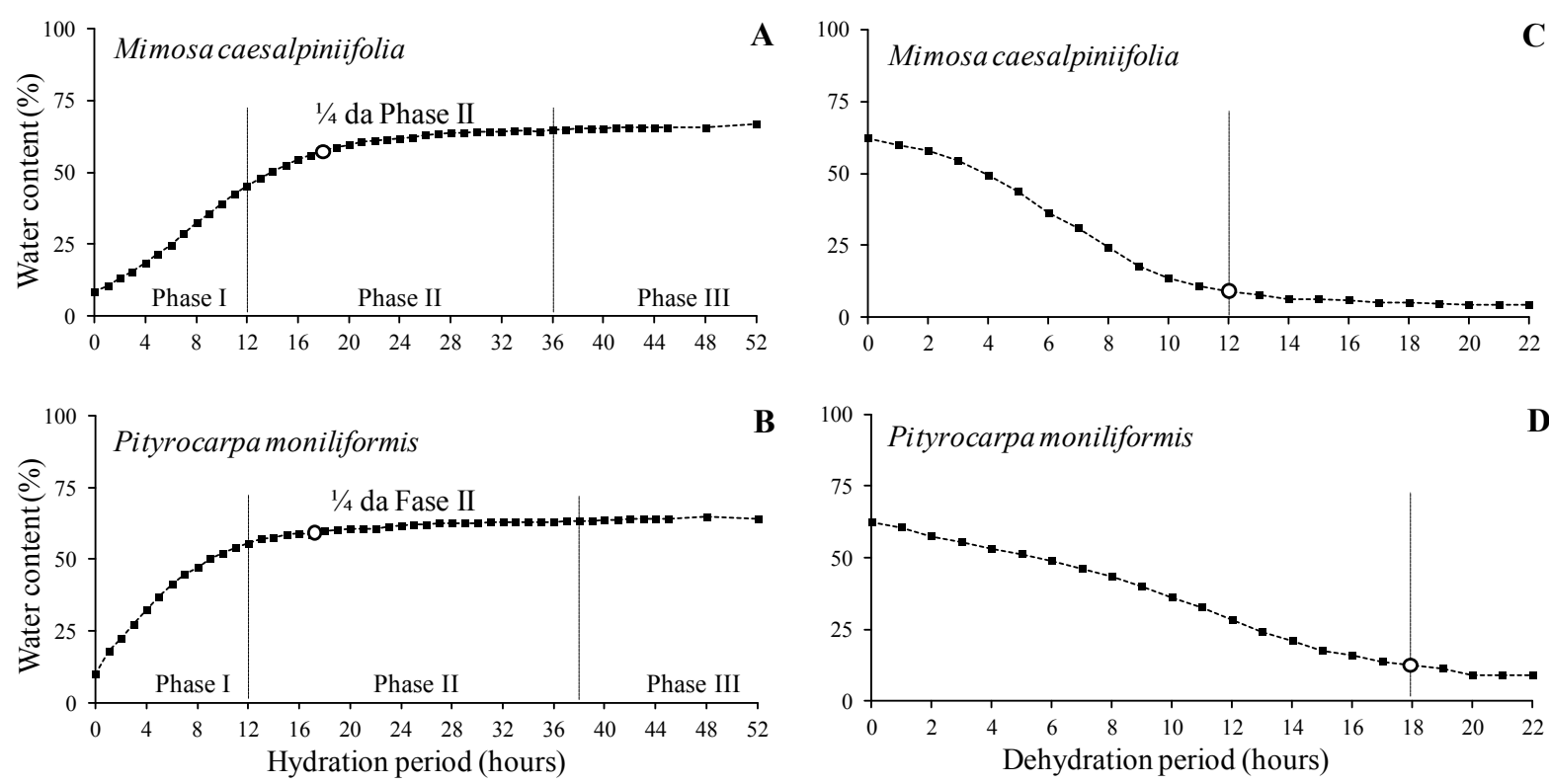

Figure 1. Water contents in the hydration and dehydration curves of Mimosa caesalpiniifolia seeds (A and C) and Pityrocarpa moniliformis seeds (B and D), respectively.

Different periods of seed dehydration for the studied species may be associated with the biochemical constitution of each species. Seeds of M. caesalpiniifolia are exalbuminous with reserve cotyledons (FREITAS et al., 2013), while those of $P$. moniliformis have an endosperm layer around the embryo, as well as reserve cotyledons (AMARO et al., 2015).

The use of hydration and dehydration cycles in $M$. caesalpiniifolia and $P$. moniliformis seeds reduced the formation of normal seedlings. Likewise, the reduction of osmotic potential negatively affected germination, being intensified with the increase in hydration cycles (Figures 2A and 2B). Therefore, the procedure of hydrating and dehydrating the seeds was harmful to the germination of these species. However, for P. moniliformis seeds, the use of two hydration cycles was more favorable to germination $(48 \%)$ under severe water stress $(-0.8 \mathrm{MPa})$, compared to those with four cycles $(10 \%)$, or without hydration (13\%) (Figure 2B). 


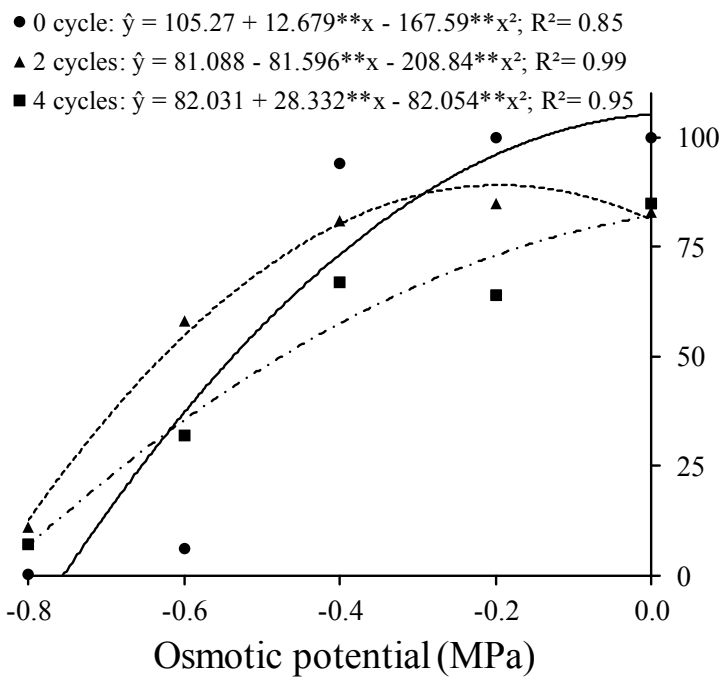

- 0 cycle: $\hat{\mathrm{y}}=95.324-69.877 * * \mathrm{x}-215.58 * * \mathrm{x}^{2} ; \mathrm{R}^{2}=0.99$
2 cycles $: \hat{\mathrm{y}}=84.343-3.5714 * * \mathrm{x}-60.714 * * \mathrm{x}^{2} ; \mathrm{R}^{2}=0.95$

\ 2 cycles: $\hat{\mathrm{y}}=84.343-3.5714 * * \mathrm{x}-60.714 * * \mathrm{x}^{2} ; \mathrm{R}^{2}=0.95$

- 4 cycles: $\hat{\mathrm{y}}=53.971+11.214 * * \mathrm{x}-55.357 * \mathrm{x}^{2} ; \mathrm{R}^{2}=0.95$

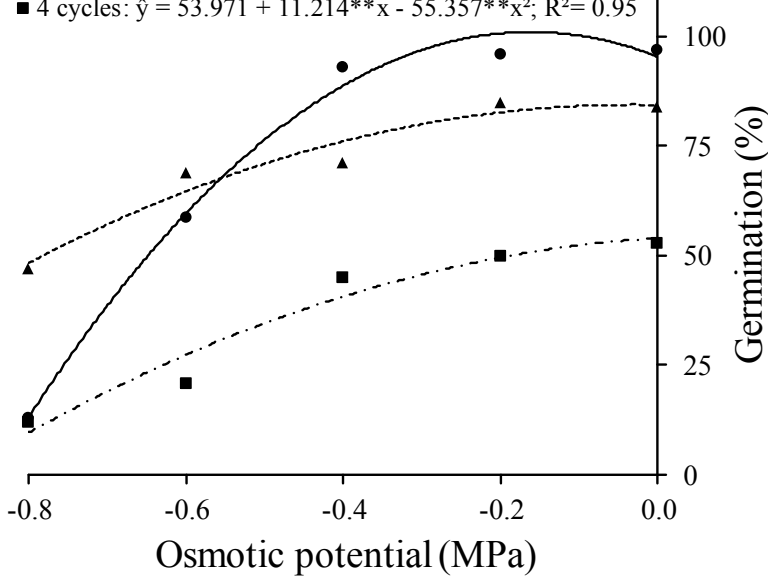

Figure 2. Germination of Mimosa caesalpiniifolia (A) and Pityrocarpa moniliformis (B) seeds with 0, 2 and 4 cycles of discontinuous hydrations and subjected to water stress.

The primary factor for the beginning of seed germination is the availability of water (BASKIN; BASKIN, 2014). Absorption results in the rehydration of tissues, promoting intensification of respiration and other metabolic activities, which contributes to the supply of energy and nutrients necessary for the resumption of embryonic axis growth (MARCOS-FILHO, 2015). Water stress leads to reduction in germination speed and germination of seeds. For each species, there is a value of water potential in the soil; if it is lower than stipulated, seed germination does not occur (AZERÊDO et al., 2016).

Plant species may exhibit different results when subjected to simulated stress (AZERÊDO et al., 2016), corroborating the results found in this study. With seeds of Myracrodruon urundeuva Allemão, Virgens et al. (2012) found that the highest germination occurred at the osmotic potentials of up to $-0.4 \mathrm{MPa}$, and from the potential of $-0.6 \mathrm{MPa}$, there was a reduction in germination, which was equal to zero at $-0.8 \mathrm{MPa}$. Seeds of $M$. caesalpiniifolia did not germinate at osmotic potential below -0.8 MPa (SOUSA et al., 2018), while for $P$. moniliformis, the germination process was inhibited between potentials from -0.6 to -1.2 MPa (AZERÊDO et al., 2016).

Studies demonstrate that seeds subjected to hydration and dehydration cycles produce plants with physiological changes (MASETTO et al., 2013). These plants become more tolerant to abiotic stresses and more vigorous under future adverse conditions and, in addition, the process promote biological and genetic changes that may be passed on to future populations (BRUCE et al., 2007).

The use of four hydration cycles caused significant loss of the physiological quality of $P$. moniliformis seeds (Figure 2B), while for $M$. caesalpiniifolia this difference was lower. Also for the latter, the loss of germination power occurred similarly for the different hydration cycles as the osmotic potential was reduced (Figure $2 \mathrm{~A}$ ).

According to Baskin and Baskin (2014), the first hydration activates biochemical mechanisms and physiological processes that prepare the seeds for germination, while the drying finishes this process. At the moment when the seeds come into contact again with water, the metabolic processes that were initially stopped are reactivated, rather than starting again from the beginning. For this reason, seed germination occurs rapidly after rehydration and the germination is more uniform (MARCOS-FILHO, 2015).

Germination speed decreased similarly for both species as the osmotic potential decreased. However, the use of two hydration cycles for $M$. caesalpiniifolia and $P$. moniliformis increased germination speed at more negative osmotic potentials (Figures 3A and 3B). This fact is associated with better preparation of the metabolic system of the seed, which reduces the permanence period of Phase II with the use of hydration and dehydration cycles. However, with four cycles of hydration and dehydration, the effect was harmful to the seeds of both species.

Water stress can cause reductions in all physiological quality parameters, as well as greater damage to the percentage and speed of seed germination, and this variation is an inherent response among species (MASETTO et al., 2013).

The speed with which seeds germinate indicates the success in the establishment of seedlings in the field (MARCOS-FILHO, 2015). For Pilosocereus catingecola (Gürke) Byles \& Rowley subsp. salvadorensis (Werderm) Zappi (Cactaceae), Lima and Meiado (2017) found that different populations have higher tolerance to water stress after the seeds were subjected to hydration and dehydration cycles. 


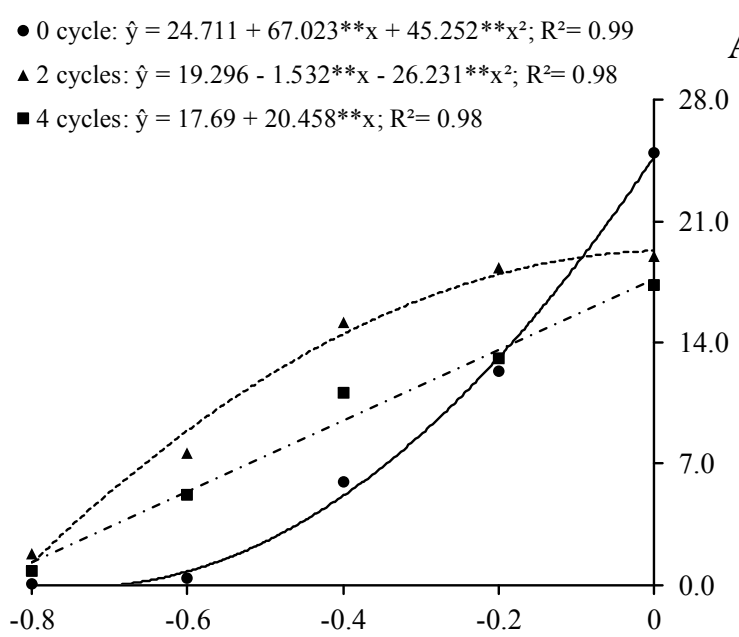

A

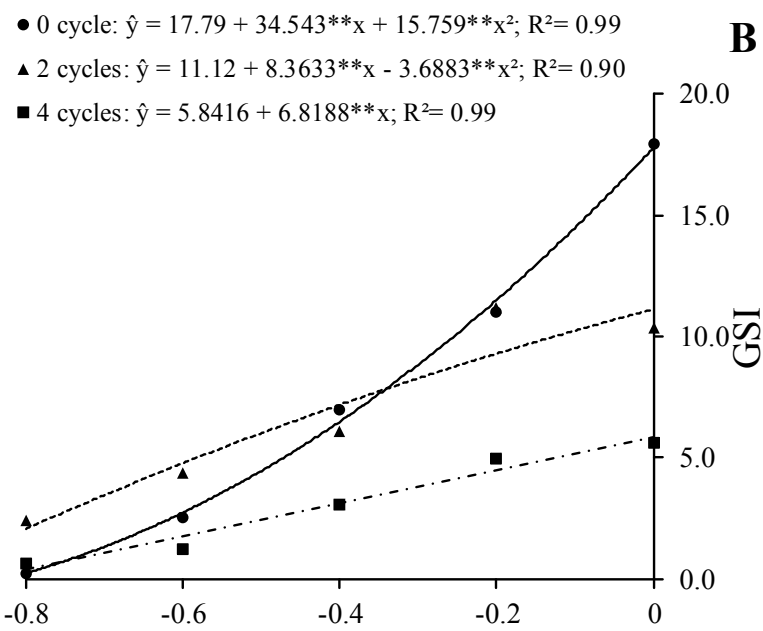

- 0 cycle: $\hat{y}=0.3447-19.626 n s x-23.985 * * x^{2} ; R^{2}=0.78$

\ 2 cycles: $\hat{\mathrm{y}}=1.0444-4.0745^{* *} \mathrm{x}-3.838^{* *} \mathrm{x}^{2} ; \mathrm{R}^{2}=0.60$

- 4 cycles: $\hat{\mathrm{y}}=1.4359+1.2246 * * \mathrm{x} ; \mathrm{R}^{2}=0.80$

- 0 cycle: $\hat{\mathrm{y}}=1.9009+1.9542 * * \mathrm{x}+20.438 * * \mathrm{x}^{2} ; \mathrm{R}^{2}=0.98$

$\triangle 2$ cycles: $\hat{y}=3.1765+1.7208^{* *} \mathrm{x}+6.0812 * * \mathrm{x}^{2} ; \mathrm{R}^{2}=0.86$

•

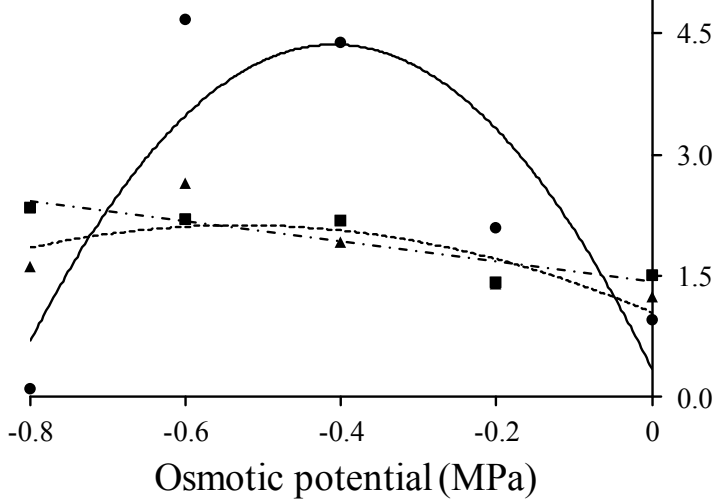

- 4 cycles: $\hat{y}=4.4802-3.5978 * * x-1.421 * * x^{2} ; R^{2}=0.84 \quad[16.0$

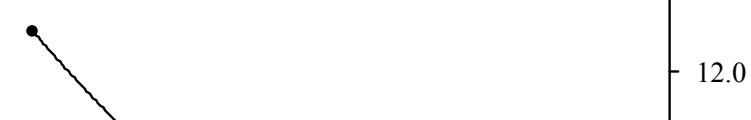

$-0.8$

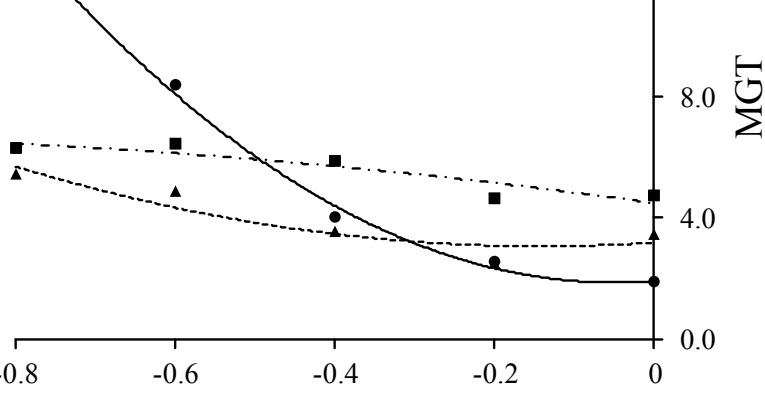

Osmotic potential (MPa)

Figure 3. Germination speed index (GSI) and mean germination time (MGT) of Mimosa caesalpiniifolia seeds (A and C) and Pityrocarpa moniliformis seeds (B and D), respectively, with 0,2 and 4 cycles of discontinuous hydration and subjected to water stress.

The mean germination time was longer for seeds that did not undergo hydration and dehydration, resulting in longer time for seedling establishment at more negative osmotic potentials (Figures 3C and 3D). One of the main effects of water stress is delaying the beginning of seed germination; however, with two hydration cycles germination occurred faster for the seeds of $M$. caesalpiniifolia and P. moniliformis.

The evaluation of seedling length has been a method widely used in the analyses seed physiological quality. This method proposes that the most vigorous seeds originate from seedlings with higher growth rate, due to the greater translocation of reserves from storage tissues to the growth of the embryonic axis (GUEDES et al., 2009).

Initially, hydration and dehydration cycles proportionally reduced the vigor of formation of the root system and shoots of the seedlings for both species studied (Figure 4). However, at more negative potentials, the seedlings formed have greater capacity to establish than those for which hydration and dehydration were not performed. Therefore, this methodology may be an alternative to be used for direct sowing in places with water restriction. In addition, as the cycles increased, there was a trend of greater emergence of secondary roots in P. moniliformis subjected to concentrations of -0.6 and $-0.8 \mathrm{MPa}$.

Studies conducted in the same line point out that, although discontinuous hydration does not have a positive influence on germination and initial development of seedlings, this technique of seed invigoration should not be prematurely discarded for the production of seedlings of tropical forest species, because its effect under stress conditions is not yet known, especially for transplanted seedlings in their natural environment (SANTOS; MEIADO, 2017).

Discontinuous hydration can also promote an increase in tolerance to water stress in the species, as the specific genes are activated in the hydration and dehydration (HD) processes, increasing the survival rate of seeds in adverse situations (LIMA; MEIADO, 2017). 


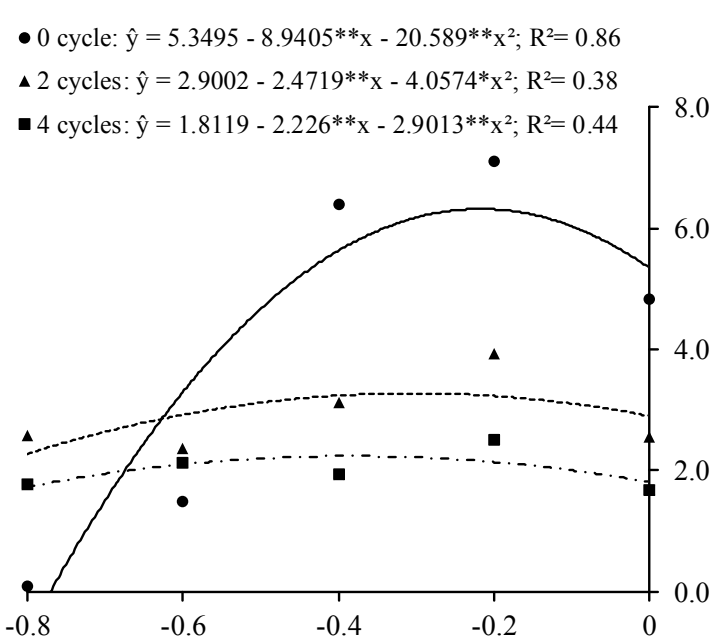

- 0 cycle: $\hat{y}=4.0937+8.055^{* *} \mathrm{x}+3.8266^{* *} \mathrm{x}^{2} ; \mathrm{R}^{2}=0.99$

$\Delta 2$ cycles: $\hat{y}=2.4973+5.047 * * x+4.0624 * * x^{2} ; R^{2}=0.99$

- 4 cycles: $\hat{\mathrm{y}}=2.0501+4.6154 * * \mathrm{x}+4.0509 * * \mathrm{x}^{2} ; \mathrm{R}^{2}=0.97$

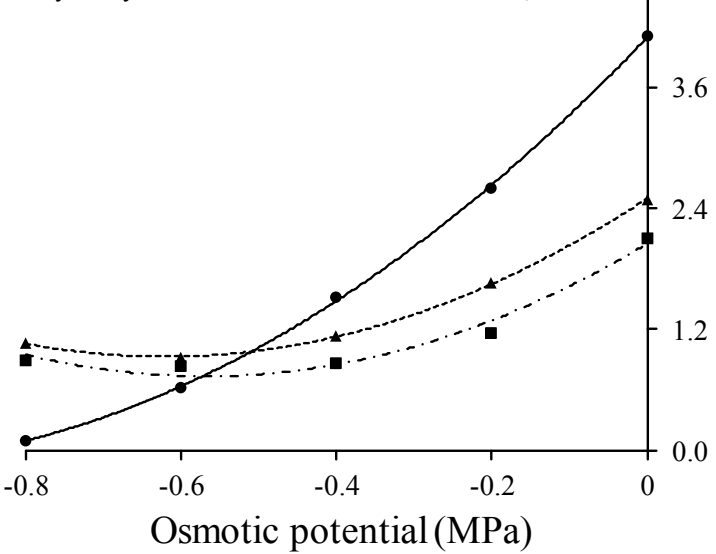

A

- 0 cycle: $\hat{y}=5.7808+4.0633 * * x ; R^{2}=0.99$

$\Delta 2$ cycles: $\hat{y}=4.3335-5.9838^{* *} \mathrm{x}-10.804 * * \mathrm{x}^{2} ; \mathrm{R}^{2}=0.83$

B

- 4 cycles: $\hat{y}=1.9966-2.4256^{* *} \mathrm{x}-2.4851^{* *} \mathrm{x}^{2} ; \mathrm{R}^{2}=0.60$
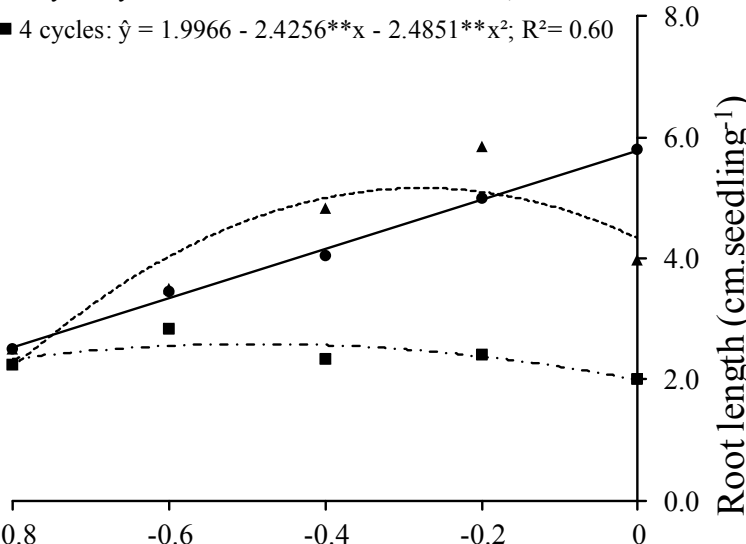

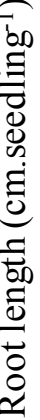

C

- 0 cycle: $\hat{\mathrm{y}}=4.415+6.1884 * * \mathrm{x}+2.099 * * \mathrm{x}^{2} ; \mathrm{R}^{2}=0.99$

D

$\Delta 2$ cycles: $\hat{y}=3.596+3.7804 * * x ; R^{2}=0.89$

- 4 cycles: $\hat{y}=1.612-3.0366^{* *} \mathrm{x}-5.6473^{* *} \mathrm{x}^{2} ; \mathrm{R}^{2}=0.88$

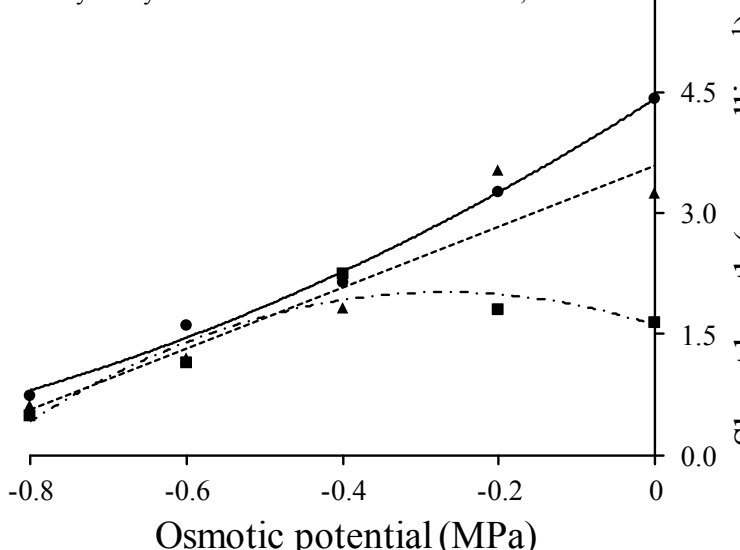

Figure 4. Root and shoot length of seedlings grown from seeds of Mimosa caesalpiniifolia seeds (A and C) and Pityrocarpa moniliformis (B and D), respectively, with 0,2 and 4 cycles of discontinuous hydration and subjected to water stress.

Water restriction and discontinuous hydration processes influenced the speed of physiological and biochemical processes, causing the seedlings of $M$. caesalpiniifolia and P. moniliformis to show lower development of shoots and root length under conditions of low water availability. The lengths of shoots and roots in hydration and dehydration cycles resulted in a lower tendency compared to the control for $P$. moniliformis. This is justified by the accumulation of fungi in the final stages of evaluation.

In all treatments, regardless of the osmotic potential tested, the incidence of fungi was noticeable. This fact can be justified because seed hydration leads to the release of solutes (organic acids, amino acids, ions and soluble sugars) that are responsible for the growth of pathogens, which can cause seed death (BEWLEY et al., 2013).

\section{CONCLUSIONS}

Discontinuous hydration in $M$ caesalpiniifolia and P. moniliformis seeds hampers germination and vigor of seedlings under water stress of up to -0.6 MPa. However, the use of two cycles in $P$. moniliformis favors germination under more severe water stress (-0.8 MPa).

\section{ACKNOWLEDGMENTS}

The study was carried out with support from the Coordenação de Aperfeiçoamento de Pessoal de Nível Superior - Brazil (CAPES) - Finance Code 001. 


\section{REFERENCES}

AMARO, H. T. R. et al. Testes de vigor para avaliação da qualidade fisiológica de sementes de feijoeiro. Revista de Ciências Agrárias, 38: 383389, 2015.

AYRES, M. et al. BioEstat 5.3: aplicações estatísticas nas áreas das Ciências Biomédicas. Sociedade Civil Mamirauá: Belém, Pará-Brasil. 2007. 324 p.

AZERÊDO, G. A. et al. Germinação de sementes de Piptadenia moniliformis Benth. sob estresse hídrico. Ciência Florestal, 26: 193-202, 2016.

BASKIN, C. C; BASKIN, J. M. Seeds: ecology, biogeography, and evolution of dormancy and germination. 2. ed. San Diego, USA: Academic/ Elsevier, 2014. 1602 p.

BEWLEY, J. D. et al. Seeds: physiology of development, germination and dormancy. 3. ed. New York: Springer, 2013. 392 p.

BRAZIL. Ministério da Agricultura, Pecuária e Abastecimento. Instruções para a análise de sementes de espécies florestais. Ministério da Agricultura, Pecuária e Abastecimento. Secretaria de Defesa Agropecuária. Brasília: MAPA/ACS, 2013. $98 \mathrm{p}$.

BRAZIL. Ministério da Agricultura, Pecuária e Abastecimento. Regras para análise de sementes. Ministério da Agricultura, Pecuária e Abastecimento. Secretaria de Defesa Agropecuária. Brasília: MAPA/ ACS, 2009. 399 p.

BRUCE, T. J. et al. Stressful "memories" of plants: evidence and possible mechanisms. Plant science, 173: 603-608, 2007.

FREITAS, T. P. et al. Morfologia e caracterização da germinação em função da posição das sementes no fruto de sabiá. Scientia Plena, 9: 1-9, 2013.

GUEDES, R. S. et al. Teste de comprimento de plântula na avaliação da qualidade fisiológica de sementes de Erythrina velutina Willd. Semina: Ciências Agrárias, 30: 793-801, 2009.

LABOURIAU, L. F. G. Germinação das sementes. Washington: Secretaria da OEA, 1983. 173 p.

LIMA, A. T.; MEIADO, M. V. Discontinuous hydration alters seed germination under stress of two populations of cactus that occur in different ecosystems in Northeast Brazil. Seed Science Research, 27: 292-302, 2017.
LIMA, A. T. et al. Does discontinuous hydration of Senna spectabilis (DC.) H.S. Irwin \& Barneby var. excelsa (Schrad.) H.S. Irwin \& Barneby (Fabaceae) seeds confer tolerance to water stress during seed germination? Journal of Seed Science, 40: 36-43, 2018.

MAGUIRE, J. D. Speed of germination aid in selection and evaluation for seedling emergence and vigor. Crop Science, 2: 176-77, 1962.

MARCOS-FILHO, J. Fisiologia de sementes de plantas cultivadas. 2. ed. Londrina, PR: ABRATES, 2015. 660 p.

MASETTO, T. E. et al. Condicionamento osmótico de sementes de Sesbania virgata (CAV.) PERS (Fabaceae). Cerne, 19: 629-636, 2013.

SANTOS, A. P.; MEIADO, M. V. Influência da hidratação descontínua na germinação de sementes e no crescimento inicial de plântulas de Amburana cearensis (Allemão) A.C. Sm. (Fabaceae). Gaia Scientia, 11: 19-25, 2017.

SOUSA, E. C. et al. Physiological changes in Mimosa caesalpiniifolia Benth. seeds from different sources and submitted to abiotic stresses. Revista Brasileira de Engenharia Agrícola e Ambiental, 22: 383-389, 2018.

VILLELA, F. A. et al. Tabela de potencial osmótico em função da concentração de Polietileno Glicol 6.000 e da temperatura. Pesquisa Agropecuária Brasileira, 26: 1957-1968, 1991.

VIRGENS, I. O. et al. Comportamento fisiológico de sementes de Myracrodruon urundeuva Fr. All. (Anacardiaceae) submetidas a fatores abióticos. Ciência Florestal, 22: 681-692, 2012. 